\title{
Polymorphisms in endoplasmic reticulum aminopeptidase genes are associated with cervical cancer risk in a Chinese Han population
}

\section{Chuanyin Li}

Chinese Academy of Medical Sciences \& Peking Union Medical College Institue of medical biology

Yaheng Li

Chinese Academy of Medical Sciences \& Peking Union Medical College Institute of Medical Biology

\section{Zhiling Yan}

Department of Gynaecologic Oncology The third Affiliated Hospital of Kunming Medical University

\section{Shuying Dai}

School of Basic Medical Science Kunming Medical University

\section{Shuyuan Liu}

Chinese Academy of Medical Sciences \& Peking Union Medical College Institute of Medical Biology

\section{Xia Wang}

Department of gynaecologic Oncology The Third Affiliated Hospital of Kunming Medical University

\section{Jun Wang}

Department of Gynaecologic Oncology The Third Affiliated Hospital of Kunming Medical University

\section{Xinwen Zhang}

Chinese Academy of Medical Sciences \& Peking Union Medical College Institute of Medical Biology

\section{Li Shi $\nabla$ shili.imb@gmail.com )}

Chinese Academy of Medical Sciences \& Peking Union Medical College Institute of Medical Biology https://orcid.org/0000-0001-9508-7863

\section{Yufeng Yao}

Chinese Academy of Medical Sciences \& Peking Union Medical College Institute of Medical Biology

\section{Research article}

Keywords: Endoplasmic reticulum aminopeptidase; Single nucleotide polymorphisms; Association; Susceptibility; Cervical intraepithelial neoplasia; Cervical cancer

Posted Date: April 2nd, 2020

DOI: https://doi.org/10.21203/rs.2.21433/v3

License: (c) (i) This work is licensed under a Creative Commons Attribution 4.0 International License. Read Full License

Version of Record: A version of this preprint was published at BMC Cancer on April 22nd, 2020. See the published version at https://doi.org/10.1186/s12885-020-06832-2. 


\section{Abstract}

Background: Antigen-processing machinery molecules play crucial roles in infectious diseases and cancers. Studies have shown that polymorphisms in endoplasmic reticulum aminopeptidase (ERAP) genes can influence the enzymatic activity of ERAP proteins and are associated with the risk of diseases. In the current study, we evaluated the influence of ERAP gene (ERAP1 and ERAP2) polymorphisms on susceptibility to cervical intraepithelial neoplasia (CIN) and cervical cancer. Methods: Six single nucleotide polymorphisms (SNPs) in ERAP1 and 5 SNPs in ERAP2 were selected and genotyped in 556 CIN patients, 1072 cervical cancer patients, and 1262 healthy control individuals. Candidate SNPs were genotyped using SNaPshot assay. And the association of these SNPs with CIN and cervical cancer was analysed. Results: The results showed that allelic and genotypic frequencies of rs26653 in ERAP1 were significantly different between cervical cancer and control groups ( $P=0.001$ and 0.004$)$. The allelic frequencies of rs 27044 in ERAP1 and rs2287988 in ERAP2 were significantly different between control and cervical cancer groups ( $P=0.003$ and 0.004$)$. Inheritance model analysis showed that genotypes of rs27044, rs26618, rs26653 and rs2287988 SNPs may be associated with the risk of cervical cancer $(P=0.003,0.004,0.001$ and 0.002$)$. Additionally, haplotype analysis results showed that the ERAP1 haplotype, rs27044C-rs30187T-rs26618T-rs26653G-rs3734016C, was associated with a lower risk of cervical cancer $(P=0.001)$. The ERAP2 haplotypes rs2549782G- rs2548538A-rs2248374A-rs2287988Grs1056893T ( $P=0.009$ and 0.006) and rs2549782T-rs2548538T-rs2248374G-rs2287988A-rs1056893T ( $P=0.003$ and 0.009 ) might be associated with cervical cancer and the development from CIN to cervical cancer. Conclusion: Our results indicated that rs27044, rs26618 and rs26653 in ERAP1 and rs2287988 in ERAP2 influenced susceptibility to cervical cancer.

\section{Background}

The antigen-processing machinery (APM) is composed of the proteasome, where exogenous and tumour antigens are degraded into peptides; transporters associated with antigen presentation (TAPs), which are responsible for the translocation of peptide precursors; endoplasmic reticulum aminopeptidases (ERAPs), which trim the peptides to fit major histocompatibility complex (MHC) molecules; and MHC proteins, which present antigen peptides on the cell surface $(1,2)$. Human ERAPs, which belong to the oxytocinase subfamily of M1 metalloproteases, are crucial molecules of the APM. In the endoplasmic reticulum lumen, ERAP1 and ERAP2 trim peptides into their final length to render them suitable for loading onto HLA class I molecules $(3,4)$. Recently, several studies have shown that ERAP proteins play crucial roles in autoimmune diseases $(5,6)$, infectious diseases $(7,8)$, and cancers $(9,10)$.

Cervical cancer is the fourth most common malignancy in women globally (11). Persistent human papillomavirus (HPV) infection confers a high risk of cervical cancer $(12,13)$. Since the HLA class I antigen-presenting system is responsible for the presentation of foreign and cancerous antigens to the immune system $(14,15)$, and ERAPs downregulation was observed in cervical cancer $(16,17)$, therefore, ERAP proteins may play crucial roles in the initiation and development of cervical cancer (18).

Previous studies revealed the association between single nucleotide polymorphisms (SNPs) in ERAP genes (such as rs26653, rs30187, rs27044, rs2549782, rs2287988, rs26618, rs3734016, rs27037, rs2248374, rs2548538 and rs1056893) and autoimmune and infectious diseases (19-22), and human cancers (23-26). Moreover, functional studies have shown that SNPs in ERAP genes could affect the enzymatic activity and selectivity of ERAP proteins (such as rs27044, and rs30187 in ERAP1 gene, rs2287988 in ERAP2 gene)(27-32), and affect the conformation of ERAP proteins (such as rs27044, rs30187 and rs26653 in ERAP1 gene; rs2549782 and rs2287988 in ERAP2 gene) (31, 33, 34). These results suggested that SNPs in ERAP genes could be valuable to be selected for association studies. Thus, in the current study, we selected 11 SNPs located in ERAP1 (rs27037, rs27044, rs30187, rs26618, rs26653 and 
rs3734016) and ERAP2 (rs2549782, rs2548538, rs2248374, 2287988 and rs1056893) and investigated their distribution in patients with cervical intraepithelial neoplasia (CIN) and cervical cancer and healthy individuals, to assess their association with the initiation and development of cervical cancer.

\section{Methods}

\section{Study population}

In the current study, a total of 556 patients with CIN and 1072 patients with cervical cancer were enrolled at the third Affiliated Hospital of Kunming Medical University from May 2014 to August 2018. The inclusion criteria were as follows: 1) diagnosis of CIN or cervical cancer according to Current Diagnosis and Treatment: Obstetrics and Gynaecology and International Federation of Gynaecology and Obstetrics (2009) guidelines; 2) no other malignancy in patients and no history of cancer or other chronic diseases in control individuals; and 3) no preoperative neoadjuvant therapies (including chemotherapy and radiotherapy). The exclusion criteria for patients were as follows: 1) a prior history of primary cancer other than cervical cancer; 2) malignant tumours other than cervical cancer; 3) currently receiving radiotherapy or chemotherapy; and 4) an unclear diagnosis. Over the same period, 1262 healthy women from a health screening project at the same hospital were enrolled as controls.

\section{SNP selection and genotyping}

Six SNPs located in ERAP1 and 5 SNPs located in ERAP2 were selected in the current study. The minor allele frequency should be over 0.05 in East Asian population (http://asia.ensembl.org/index.html). The details of the selected SNPs are displayed in Supplementary Table 1. Venous blood samples were collected for the extraction of genomic DNA, using the QIAamp Blood Mini Kit (Qiagen NV, Venlo, Netherlands). Genotyping of the 11 SNPs was performed using the SNaPshot SNP assay (Thermo Fisher Scientific, Waltham, MA, USA), and results were analysed using GeneMapper TM 4.0 software (Applied Biosystems, Foster City, CA, USA). For quality control, $5 \%$ of samples from the case and control groups were genotyped twice with unique analysis serial numbers and the reproducibility was found to be $100 \%$.

\section{Statistical analysis}

Hardy-Weinberg equilibrium (HWE) was evaluated to determine the representativeness of the study population. The differences in age among the $\mathrm{CIN}$, cervical cancer, and control groups were analysed using a one-way ANOVA, with a least significant difference test for multiple comparison correction. Allelic and genotypic frequencies of these SNPS were compared between different groups using a Chi-square test and odds ratios (ORs) with associated $95 \%$ confidence intervals (Cls) were calculated. Additionally, linkage disequilibrium (LD) was calculated and a $D^{\prime}$ value greater than 0.80 was considered to indicate LD. The haplotypes among these SNPs were analysed using SHEsis software $(35,36)$. Subsequently, the distribution of the haplotypes between different groups was compared using a Chisquare test. In addition, inheritance analysis adjusted by age was performed using SNPstats software to identify the relationship between genotypes at these SNPs and cervical cancer (37). In the inheritance analysis, four inheritance models (codominant, dominant, recessive, and log-additive) were analysed. Simultaneously, Akaike information criterion (AIC) and Bayesian information criterion (BIC) values were calculated to determine the inheritance model with the best fit, i.e. the model with the smallest AIC and BIC values (37). The statistical power was calculated using Power and Sample Size software (V3.1.2) (38). Bonferroni correction was performed for multiple comparisons, after which the statistical significance threshold was set at $P<0.0045(0.05 / 11)$.

\section{Results}




\section{Characteristics of the subjects}

Table 1 shows the clinical data of the subjects in the present study. There was no significant difference in age among the control, CIN, and cervical cancer groups $(P>0.05, F=1.438)$, as evaluated by one-way ANOVA. In the CIN group, there were 65 patients with low-grade $\mathrm{CIN}(\mathrm{I} / \mathrm{II})$ and 491 patients with high-grade CIN (III). In the cervical cancer group, there were 151 patients with adenocarcinoma, 903 patients with squamous cell carcinoma, and 18 patients with other pathological types.

\section{Association of the eleven SNPs with CIN and cervical cancer}

All 11 SNPs were in HWE in the control group $(P>0.05)$ (Supplementary Table 1$)$. The allelic and genotypic frequencies of these SNPs are presented in Tables 2 and 3. The results showed that the allelic and genotypic frequencies of rs26618 $(P=0.021$ and 0.016 , respectively), rs26653 $(P=0.001$ and 0.004$)$, rs27044 $(P=0.003$ and 0.012$)$ and rs30187 $(P=0.008$ and 0.020$)$ in ERAP1 (Table 2) and rs2248374 $(P=0.014$ and 0.020$)$ and rs2287988 $(P=0.004$ and 0.007 ) in ERAP2 (Table 3) were significantly different between cervical cancer and control groups. Additionally, the allelic and genotypic distributions of rs2248374 ( $P=0.015$ and 0.041 , respectively) and rs2287988 $(P=0.014$ and $0.039)$ in ERAP2 were significantly different between CIN and cervical cancer groups (Table 3). However, after Bonferroni correction, only rs26653, rs27044, and rs2287988 were associated with cervical cancer risk $(P<0.0045)$. The results indicated that, in ERAP1, the $\mathrm{G}$ allele of rs 26653 may be associated with a lower risk of cervical cancer compared with $\mathrm{C}$ allele $(\mathrm{OR}=0.829 ; 95 \% \mathrm{Cl}: 0.738-0.930)$ and the $\mathrm{G}$ allele of rs27044 may be a risk factor for cervical cancer $(\mathrm{OR}=1.193,95 \% \mathrm{Cl}: 1.062-1.340)$. Moreover, the A allele of rs2287988 in ERAP2 may be associated with a lower risk of cervical cancer $(\mathrm{OR}=0.843,95 \% \mathrm{Cl}$ : 0.751-0.946). There were no SNPs in ERAP1 (Table 2) or ERAP2 (Table 3) that exhibited a significantly different distribution between the CIN and control groups or between the CIN and cervical cancer groups after Bonferroni correction $(P>0.0045)$.

\section{Inheritance model analysis}

To evaluate the genotypic association of the 11 SNPs with CIN and cervical cancer, inheritance analysis was performed among cervical cancer, CIN, and control groups (Table 4, Table 5, and Supplementary Tables 2-5). The CC genotype of rs26618 was a risk factor for cervical cancer, compared with TT-CT genotype $(P=0.004 ; \mathrm{OR}=1.53,95 \% \mathrm{Cl}$ : $1.14-2.05)$ in the recessive model (the best-fit inheritance model for the comparison between control and cervical cancer groups) (Table 4). The $2 \mathrm{GG}+\mathrm{CG}$ genotype of rs 26653 was associated with a lower risk of cervical cancer compared with the CC genotype $(P=0.001, \mathrm{OR}=0.82 ; 95 \% \mathrm{Cl}$ : 0.73-0.93) in the log-additive model (the best-fit inheritance model for the comparison between control and cervical cancer groups) (Table 4). The 2CC+CG genotype of rs27044 may be a protective factor against cervical cancer compared with the GG genotype $(P=0.003, \mathrm{OR}=0.84 ; 95 \% \mathrm{Cl}$ : 0.75-0.94) in the log-additive model (the best-fit inheritance model for the comparison between control and cervical cancer groups) (Table 4) and the GG+GA genotype of rs2287988 may be a risk factor for cervical cancer compared with the AA genotype $(P=0.002, O R=1.33 ; 95 \% \mathrm{Cl}: 1.11-1.60)$ in the dominant model (the best fit inheritance model for the comparison between control and cervical cancer groups) (Table 5).

\section{Linkage Disequilibrium (LD) and haplotype analysis of SNPs in ERAP1 and ERAP2}

The results of LD analysis showed that rs26618, rs26653, rs27044, rs30187, and rs3734016 in ERAP1 and rs2248374, rs2549782, rs2287988, rs2548538, and rs1056893 in ERAP2 were in LD ( $\left.D^{\prime}>0.80\right)$ (Supplementary Tables 6, 7). Subsequently, we constructed the haplotypes, rs27044-rs30187-rs26618-rs26653-rs3734016 and rs2549782rs2548538-rs2248374-rs2287988-rs1056893. The distribution of these haplotypes (with a frequency of more than 3\%) was compared in a pairwise manner among the cervical cancer, $\mathrm{CIN}$, and control groups (Tables 6 and 7). The ERAP1 haplotype, rs27044C-rs30187T-rs26618T-rs26653G-rs3734016C, was associated with a lower risk of cervical cancer $(P$ 
$=0.001 ; \mathrm{OR}=0.804,95 \% \mathrm{Cl}: 0.711-0.910)$ (Table 6). The distribution of haplotypes rs2549782G-rs2548538Ars2248374A-rs2287988G-rs1056893T and rs2549782T-rs2548538T-rs2248374G-rs2287988A-rs1056893T in ERAP2 (Table 7) were significantly different in the control $(P=0.009$ and 0.003 , respectively) and $\mathrm{CIN}(P=0.006$ and 0.009$)$ groups compared with the cervical cancer group. The results indicated that rs2549782G-rs2548538A-rs2248374Ars2287988G-rs1056893T may be associated with a higher risk of cervical cancer (OR $=1.592,95 \% \mathrm{Cl}: 1.122-2.258)$ and the progression from $\mathrm{CIN}$ to cervical cancer $(\mathrm{OR}=2.000,95 \% \mathrm{Cl}: 1.215-3.292)$. Moreover, rs2549782T-rs2548538Trs2248374G-rs2287988A-rs1056893T may be associated with a lower risk of cervical cancer $(\mathrm{OR}=0.835,95 \% \mathrm{Cl}$ : $0.740-0.942)$ and the progression from $\mathrm{CIN}$ to cervical cancer $(\mathrm{OR}=0.817,95 \% \mathrm{Cl}: 0.702-0.951)$.

\section{Discussion}

The immune system is activated by MHC-peptide complexes, after which it eliminates infected and cancerous cells in various ways. The APM plays crucial roles in the initiation and development of various human diseases. As components of the APM, ERAP1 and ERAP2 are important determinants of the repertoire of peptides ultimately presented by HLA class I molecules (39-42). Moreover, the SNPs in ERAP genes have been shown to affect the function of ERAPs by changing their peptidome or enzymatic activity $(29,30,43)$. In cervical cancer, ERAP1 and ERAP2 proteins have been reported to be highly variable, ranging from low to high expression levels (44-46). Although there are inconsistencies among these studies, it is clear that the dysregulated expression of ERAP proteins, which may be induced by ERAP gene SNPs $(47,48)$, is associated with cervical cancer risk.

In 2007, Mehta et al. found that rs27044 in ERAP1 was associated with cervical cancer risk. In the current study, rs27044 was found to be associated with cervical cancer risk $(P=0.003)$. The $\mathrm{G}$ allele of rs27044 (Q730) was found to be a risk factor for cervical cancer (OR $=1.193,95 \% \mathrm{Cl}$ : 1.062-1.340) (Table 2), which was consistent with the results of Mehta's study (24). The SNP, rs27044, a non-synonymous polymorphism, leads to a Q730E substitution in the IV catalysis domain of ERAP1 (33) and may change the substrate length preferences of ERAP1 (49). Therefore, rs27044 may play a role in cervical cancer by affecting ERAP1 function.

The SNP, rs26618, in ERAP1 leads to an amino acid substitution (I276M) and the current study showed that the CC genotype of this SNP may be associated with an increased risk of cervical cancer (OR $=1.53 ; 95 \% \mathrm{Cl}$ : 1.14-2.05) compared with TT-CT genotypes (Table 4). In 2016, Guasp et al. reported that I276M (rs26618) may affect the peptidome of ERAP1 by destroying peptides with p2 Ala, unless the p1 amino acid was resistant to ERAP1 trimming (43), which indicated that rs26618 may be associated with cervical cancer. However, in a Netherlands population, Mehta et al. reported no association between rs26618 and cervical carcinoma. One of the reasons of inconsistency between our data and Mehta et al. could be the different sample sizes and statistical power. The sample size used by Mehta et al. was 251 individuals and the statistical power of rs26618 is 0.141 , while 2,890 individuals were enrolled in the current study and the statistical power of the same SNP is 0.621. In addition, the different population genetic background could be another reason.

In 2007, Mehta et al. reported that the $\mathrm{C}$ allele of rs26653 in ERAP1 was associated with a higher cervical cancer risk in a Netherlands population (24). In the current study, the G allele (OR $=0.829 ; 95 \% \mathrm{Cl}: 0.738-0.930)$ (Table 2), compared to the $\mathrm{C}$ allele, and the $2 \mathrm{GG}+\mathrm{CG}$ genotype, compared to the CC genotype (OR $=0.82 ; 95 \% \mathrm{Cl}: 0.73-0.93)$ of rs26653, were associated with lower cervical cancer risk (Table 4). In 2014, Stratikos et al. and Alvarez-Navarro et al. reported that rs26653, which is a non-synonymous polymorphism resulting in a P127R substitution, may be associated with ERAP expression $(49,50)$, and this substitution may also affect the enzymatic activity of ERAP1 in the editing of tumour antigen peptides. This finding may explain the association between rs26653 and cervical cancer risk; however, the mechanisms need to be determined in functional studies. 
In the current study, we found an association between rs2287988 in ERAP2, which is responsible for a synonymous polymorphism (Q563Q), and cervical cancer. The A allele may be associated with a lower risk of cervical cancer $(P=$ $0.004 ; \mathrm{OR}=0.843,95 \% \mathrm{Cl}: 0.751-0.946)$ (Table 3). Moreover, the GG-GA genotype was associated with an increased risk of cervical cancer $(P=0.002 ; \mathrm{OR}=1.33,95 \% \mathrm{Cl}$ : 1.11-1.60) (Table 5). However, association studies of this SNP are rare. Previous studies have found that ERAP2 haplotypes containing rs2287988 affect ERAP2 splicing and expression (51, 52). Thus, additional association studies in different populations are necessary to investigate the role of this polymorphism during the initiation and development of cervical cancer.

ERAPs are markedly polymorphic and ERAP haplotypes whose protein products differ at multiple amino acids may affect peptide editing by $\operatorname{ERAPs}(29,30,53,54)$. In the current study, we also analysed haplotypes of ERAPSNPS in LD. The results showed that the ERAP1 haplotype, rs27044C-rs30187T-rs26618T-rs26653G-rs3734016C and the ERAP2 haplotypes, rs2549782T-rs2548538T-rs2248374G-rs2287988A-rs1056893T and rs2549782G-rs2548538A-rs2248374Ars2287988G-rs1056893T may be associated with cervical cancer risk. These results indicated that SNPs in polymorphic genes may have combinatorial effects on disease susceptibility.

\section{Conclusion}

Studies indicated that genetic factors might be correlated with cervical cancer risk (55-57), the clinical parameters of cervical cancer $(58,59)$ and the clinical outcome of cervical cancer $(60,61)$. In the current study, we found that genetic polymorphisms in ERAP1 and ERAP2 genes might be associated with CIN and cervical cancer, and suggested that polymorphisms in key antigen-processing genes could affect susceptibility of cervical cancer. The strength of our study could be we investigated the association of ERAP SNPs with different stages of cervical cancer (healthy individuals, $\mathrm{CIN}$ and cervical cancer patients). By contrary, the limitations of our study are that we could not collect more details of the patients' clinical parameters and had no functional verification. Association studies can only provide preliminary results for the correlation between genetic factors and cervical cancer susceptibility, the determination of the SNPs' roles in cervical cancer requires functional studies to be resolved in the future.

\section{Abbreviations}

Endoplasmic reticulum aminopeptidase: ERAP; Single nucleotide polymorphisms: SNPs; Antigen-processing machinery: APM; Transporters associated with antigen presentation: TAPs; Major histocompatibility complex: MHC; Human papillomavirus: HPV; Hardy-Weinberg equilibrium: HWE; Odds ratios: ORs; Cervical intraepithelial neoplasia: CIN; squamous cell carcinoma: SCC; Adenocarcinoma: AC; confidence intervals: Cls; Linkage disequilibrium: LD; Akaike information criterion: AIC; Bayesian information criterion: BIC.

\section{Declarations}

\section{Ethics approval and consent to participate}

The current study was approved by the Institutional Review Boards of the No. 3 Affiliated Hospitals of Kunming Medical University and was performed in accordance with the principles of the Declaration of Helsinki. All individuals enrolled in this study provided written informed consent.

\section{Consent for publication}

Not applicable.

\section{Availability of data and materials}


The data generated during the current study are available to any scientist wishing to use them for non-commercial purpose from the corresponding author on reasonable request. However, the clinical data might be available without the privacy data of participates in the current study.

\section{Competing interests}

The authors declare that they have no competing interests.

\section{Funding}

The current study was supported by grant from the National Natural Science Foundation of China (81573206), Yunnan Applied Basic Research Projects (2016FA034), The PUMC Youth Fund (3332019111), Special Funds for High-level Healthy Talents of Yunnan Province (D-201669 and L-201615), CAMS Innovation Fund for Medical Sciences (2016I2M-2-001), Yunnan Provincial Science and Technology Department (2019HC0060), Association Foundation Program of Yunnan Provincial Science and Technology Department and Kunming Medical University (2017FR467-077 and 2017FE467-012). The funders had no role in study design, data collection and analysis, decision to publish or preparation of the manuscript.

\section{Authors' contributions}

LS and YFY designed the current study; CYL and YHL finished the main part of experiment and data analysis of the current study; ZLY and SYD finished the sample clinical diagnose and collection; XW and JW were responsible for the collection of venous blood; SYL and XWZ participated in the genomic DNA extraction; CYL and YHL drafted the manuscript; LS and YFY revised the manuscript. And all authors have read and approved the manuscript.

\section{Acknowledgement}

Our great gratitude was expressed to the participation of the patients and control subjects in current study.

\section{References}

1. Germain RN, Margulies DH. The biochemistry and cell biology of antigen processing and presentation. Annu Rev Immunol. 1993;11:403-50.

2. Heemels MT, Ploegh H. Generation, translocation, and presentation of MHC class I-restricted peptides. Annu Rev Biochem. 1995;64:463-91.

3. Vyas JM, Van der Veen AG, Ploegh HL. The known unknowns of antigen processing and presentation. Nature reviews Immunology. 2008;8(8):607-18.

4. Saric T, Chang SC, Hattori A, York IA, Markant S, Rock KL, et al. An IFN-gamma-induced aminopeptidase in the ER, ERAP1, trims precursors to MHC class I-presented peptides. Nature immunology. 2002;3(12):1169-76.

5. Pepelyayeva Y, Amalfitano A. The role of ERAP1 in autoinflammation and autoimmunity. Human immunology. 2019;80(5):302-9.

6. Reeves E, James E. The role of polymorphic ERAP1 in autoinflammatory disease. Bioscience reports. 2018;38(4).

7. Lorente E, Barriga A, Johnstone C, Mir C, Jimenez M, Lopez D. Concerted in vitro trimming of viral HLA-B27restricted ligands by human ERAP1 and ERAP2 aminopeptidases. PloS one. 2013;8(11):e79596.

8. Cifaldi L, Romania P, Lorenzi S, Locatelli F, Fruci D. Role of endoplasmic reticulum aminopeptidases in health and disease: from infection to cancer. International journal of molecular sciences. 2012;13(7):8338-52. 
9. Compagnone M, Cifaldi L, Fruci D. Regulation of ERAP1 and ERAP2 genes and their disfunction in human cancer. Human immunology. 2019;80(5):318-24.

10. Stoehr CG, Buettner-Herold M, Kamphausen E, Bertz S, Hartmann A, Seliger B. Comparative expression profiling for human endoplasmic reticulum-resident aminopeptidases 1 and 2 in normal kidney versus distinct renal cell carcinoma subtypes. International journal of clinical and experimental pathology. 2013;6(6):998-1008.

11. Torre LA, Bray F, Siegel RL, Ferlay J, Lortet-Tieulent J, Jemal A. Global cancer statistics, 2012. CA: a cancer journal for clinicians. 2015;65(2):87-108.

12. Walboomers JM, Jacobs MV, Manos MM, Bosch FX, Kummer JA, Shah KV, et al. Human papillomavirus is a necessary cause of invasive cervical cancer worldwide. J Pathol. 1999;189(1):12-9.

13. Munoz N. Human papillomavirus and cancer: the epidemiological evidence. Journal of clinical virology : the official publication of the Pan American Society for Clinical Virology. 2000;19(1-2):1-5.

14. Delves PJ, Roitt IM. The immune system. First of two parts. The New England journal of medicine. 2000;343(1):3749.

15. Paaso A, Jaakola A, Syrjänen S, Louvanto K. From HPV Infection to Lesion Progression: The Role of HLA Alleles and Host Immunity. Acta Cytol. 2019;63(2):148-58.

16. Mehta AM, Michelle O, Sandra K-U, Jan FG, S. JE. Molecular Backgrounds of ERAP1 Downregulation in Cervical Carcinoma. Analytical Cellular Pathology.2015:1-5.

17. Mirco, Compagnone, Loredana, Cifaldi, Doriana, Fruci. Regulation of ERAP1 and ERAP2 genes and their disfunction in human cancer.

18. Stratikos E, Stamogiannos A, Zervoudi E, Fruci D. A Role for Naturally Occurring Alleles of Endoplasmic Reticulum Aminopeptidases in Tumor Immunity and Cancer Pre-Disposition. Frontiers in oncology.4.

19. Wang J, Li H, Wang J, Gao X. Association between ERAP1 gene polymorphisms and ankylosing spondylitis susceptibility in Han population. International journal of clinical and experimental pathology. 2015;8(9):11641-6.

20. Hill LD, Hilliard DD, York TP, Srinivas S, Kusanovic JP, Gomez R, et al. Fetal ERAP2 variation is associated with preeclampsia in African Americans in a case-control study. BMC medical genetics. 2011;12:64.

21. Cagliani R, Riva S, Biasin M, Fumagalli M, Pozzoli U, Lo Caputo S, et al. Genetic diversity at endoplasmic reticulum aminopeptidases is maintained by balancing selection and is associated with natural resistance to HIV-1 infection. Human molecular genetics. 2010;19(23):4705-14.

22. Liu S, Cao D, Shen Y, Li Y, Li Y, Shi L, et al. The ERAP gene is associated with HCV chronic infection in a Chinese Han population. Hum Immunol. 2017;78(11-12):731-8.

23. Yao Y, Wisniewski A, Ma Q, Kowal A, Porebska I, Pawelczyk K, et al. Single Nucleotide Polymorphisms of the ERAP1 Gene and Risk of NSCLC: A Comparison of Genetically Distant Populations, Chinese and Caucasian. Arch Immunol Ther Exp (Warsz). 2016;64(Suppl 1):117-22.

24. Mehta AM, Jordanova ES, van Wezel T, Uh HW, Corver WE, Kwappenberg KM, et al. Genetic variation of antigen processing machinery components and association with cervical carcinoma. Genes Chromosomes Cancer. 2007;46(6):577-86.

25. Mehta AM, Jordanova ES, Corver WE, van Wezel T, Uh HW, Kenter GG, et al. Single nucleotide polymorphisms in antigen processing machinery component ERAP1 significantly associate with clinical outcome in cervical carcinoma. Genes Chromosomes Cancer. 2009;48(5):410-8.

26. Mehta AM, Spaans VM, Mahendra NB, Osse EM, Vet JN, Purwoto G, et al. Differences in genetic variation in antigen-processing machinery components and association with cervical carcinoma risk in two Indonesian populations. Immunogenetics. 2015;67(5-6):267-75. 
27. Birtley JR, Saridakis E, Stratikos E, Mavridis IM. The crystal structure of human endoplasmic reticulum aminopeptidase 2 reveals the atomic basis for distinct roles in antigen processing. Biochemistry. 2012;51(1):28695.

28. Mpakali A, Giastas P, Mathioudakis N, Mavridis IM, Saridakis E, Stratikos E. Structural Basis for Antigenic Peptide Recognition and Processing by Endoplasmic Reticulum (ER) Aminopeptidase 2. The Journal of biological chemistry. 2015;290(43):26021-32.

29. Stamogiannos A, Koumantou D, Papakyriakou A, Stratikos E. Effects of polymorphic variation on the mechanism of Endoplasmic Reticulum Aminopeptidase 1. Molecular immunology. 2015;67(2 Pt B):426-35.

30. Evnouchidou I, Kamal RP, Seregin SS, Goto Y, Tsujimoto M, Hattori A, et al. Cutting Edge: Coding single nucleotide polymorphisms of endoplasmic reticulum aminopeptidase 1 can affect antigenic peptide generation in vitro by influencing basic enzymatic properties of the enzyme. Journal of immunology (Baltimore, Md : 1950). 2011;186(4):1909-13.

31. Evnouchidou I, Birtley J, Seregin S, Papakyriakou A, Zervoudi E, Samiotaki M, et al. A common single nucleotide polymorphism in endoplasmic reticulum aminopeptidase 2 induces a specificity switch that leads to altered antigen processing. Journal of immunology (Baltimore, Md : 1950). 2012;189(5):2383-92.

32. Zervoudi E, Papakyriakou A, Georgiadou D, Evnouchidou I, Gajda A, Poreba M, et al. Probing the S1 specificity pocket of the aminopeptidases that generate antigenic peptides. The Biochemical journal. 2011;435(2):411-20.

33. Hattori A, Tsujimoto M. Endoplasmic reticulum aminopeptidases: biochemistry, physiology and pathology. Journal of biochemistry. 2013;154(3):219-28.

34. Nguyen TT, Chang SC, Evnouchidou I, York IA, Zikos C, Rock KL, et al. Structural basis for antigenic peptide precursor processing by the endoplasmic reticulum aminopeptidase ERAP1. Nature structural \& molecular biology. 2011;18(5):604-13.

35. Li Z, Zhang Z, He Z, Tang W, Li T, Zeng Z, et al. A partition-ligation-combination-subdivision EM algorithm for haplotype inference with multiallelic markers: update of the SHEsis (http://analysis.bio-x.cn). Cell Res. 2009;19(4):519-23.

36. Shi YY, He L. SHEsis, a powerful software platform for analyses of linkage disequilibrium, haplotype construction, and genetic association at polymorphism loci. Cell Res. 2005;15(2):97-8.

37. Sole X, Guino E, Valls J, Iniesta R, Moreno V. SNPStats: a web tool for the analysis of association studies. Bioinformatics. 2006;22(15):1928-9.

38. Dupont WD, Plummer WD, Jr. Power and sample size calculations. A review and computer program. Control Clin Trials. 1990;11(2):116-28.

39. Falk K, Rotzschke O. The final cut: how ERAP1 trims MHC ligands to size. Nature immunology. 2002;3(12):1121-2.

40. York IA, Chang SC, Saric T, Keys JA, Favreau JM, Goldberg AL, et al. The ER aminopeptidase ERAP1 enhances or limits antigen presentation by trimming epitopes to 8-9 residues. Nature immunology. 2002;3(12):1177-84.

41. Chang SC, Momburg F, Bhutani N, Goldberg AL. The ER aminopeptidase, ERAP1, trims precursors to lengths of $\mathrm{MHC}$ class I peptides by a "molecular ruler" mechanism. Proceedings of the National Academy of Sciences of the United States of America. 2005;102(47):17107-12.

42. Saveanu L, Carroll O, Lindo V, Del Val M, Lopez D, Lepelletier Y, et al. Concerted peptide trimming by human ERAP1 and ERAP2 aminopeptidase complexes in the endoplasmic reticulum. Nature immunology. 2005;6(7):689-97.

43. Guasp P, Alvarez-Navarro C, Gomez-Molina P, Martin-Esteban A, Marcilla M, Barnea E, et al. The Peptidome of Behcet's Disease-Associated HLA-B*51:01 Includes Two Subpeptidomes Differentially Shaped by Endoplasmic Reticulum Aminopeptidase 1. Arthritis \& rheumatology (Hoboken, NJ). 2016;68(2):505-15. 
44. Mehta AM, Jordanova ES, Kenter GG, Ferrone S, Fleuren GJ. Association of antigen processing machinery and HLA class I defects with clinicopathological outcome in cervical carcinoma. Cancer Immunol Immunother. 2008;57(2):197-206.

45. Uhlen M, Fagerberg L, Hallstrom BM, Lindskog C, Oksvold P, Mardinoglu A, et al. Proteomics. Tissue-based map of the human proteome. Science (New York, NY). 2015;347(6220):1260419.

46. Steinbach A, Winter J, Reuschenbach M, Blatnik R, Klevenz A, Bertrand M, et al. ERAP1 overexpression in HPVinduced malignancies: A possible novel immune evasion mechanism. Oncoimmunology. 2017;6(7):e1336594.

47. Costantino F, Talpin A, Evnouchidou I, Kadi A, Leboime A, Said-Nahal R, et al. ERAP1 Gene Expression Is Influenced by Nonsynonymous Polymorphisms Associated With Predisposition to Spondyloarthritis. Arthritis \& rheumatology (Hoboken, NJ). 2015;67(6):1525-34.

48. Hanson AL, Cuddihy T, Haynes K, Loo D, Morton CJ, Oppermann U, et al. Genetic Variants in ERAP1 and ERAP2 Associated With Immune-Mediated Diseases Influence Protein Expression and the Isoform Profile. Arthritis \& rheumatology (Hoboken, NJ). 2018;70(2):255-65.

49. Alvarez-Navarro C, Lopez de Castro JA. ERAP1 structure, function and pathogenetic role in ankylosing spondylitis and other MHC-associated diseases. Mol Immunol. 2014;57(1):12-21.

50. Stratikos E, Stamogiannos A, Zervoudi E, Fruci D. A role for naturally occurring alleles of endoplasmic reticulum aminopeptidases in tumor immunity and cancer pre-disposition. Frontiers in oncology. 2014;4:363.

51. Andres AM, Dennis MY, Kretzschmar WW, Cannons JL, Lee-Lin SQ, Hurle B, et al. Balancing selection maintains a form of ERAP2 that undergoes nonsense-mediated decay and affects antigen presentation. PLoS genetics. 2010;6(10):e1001157.

52. Vanhille DL, Hill LD, Hilliard DD, Lee ED, Teves ME, Srinivas S, et al. A Novel ERAP2 Haplotype Structure in a Chilean Population: Implications for ERAP2 Protein Expression and Preeclampsia Risk. Molecular genetics \& genomic medicine. 2013;1(2):98-107.

53. Goto Y, Hattori A, Ishii Y, Tsujimoto M. Reduced activity of the hypertension-associated Lys528Arg mutant of human adipocyte-derived leucine aminopeptidase (A-LAP)/ER-aminopeptidase-1. FEBS letters. 2006;580(7):18338.

54. Kochan G, Krojer T, Harvey D, Fischer R, Chen L, Vollmar M, et al. Crystal structures of the endoplasmic reticulum aminopeptidase-1 (ERAP1) reveal the molecular basis for $\mathrm{N}$-terminal peptide trimming. Proceedings of the National Academy of Sciences of the United States of America. 2011;108(19):7745-50.

55. Chen D, Gyllensten U. Lessons and implications from association studies and post-GWAS analyses of cervical cancer. Trends in genetics : TIG. 2015;31(1):41-54.

56. Hildesheim A, Wang SS. Host and viral genetics and risk of cervical cancer: a review. Virus Res. 2002;89(2):229-40.

57. Martínez-Nava GA, Fernández-Niño JA, Madrid-Marina V, Torres-Poveda K. Cervical Cancer Genetic Susceptibility: A Systematic Review and Meta-Analyses of Recent Evidence. PloS one. 2016;11(7):e0157344-e.

58. Weng S-L, Wu W-J, Hsiao Y-H, Yang S-F, Hsu C-F, Wang P-H. Significant association of long non-coding RNAs HOTAIR genetic polymorphisms with cancer recurrence and patient survival in patients with uterine cervical cancer. International journal of medical sciences. 2018;15(12):1312-9.

59. Han S-S, Kim JW, Lee SH, Kim DH, Park N-H, Song Y-S, et al. ERCC1 C19007T polymorphism and the risk and invasiveness of cervical cancer in Korean women. Asia Pac J Clin Oncol. 2012;8(4):e63-e7.

60. Nogueira A, Catarino R, Faustino I, Nogueira-Silva C, Figueiredo T, Lombo L, et al. Role of the RAD51 G172T polymorphism in the clinical outcome of cervical cancer patients under concomitant chemoradiotherapy. Gene. 2012;504(2):279-83. 
61. Shi T-Y, Cheng X, Yu K-D, Sun M-H, Shao Z-M, Wang M-Y, et al. Functional variants in TNFAIP8 associated with cervical cancer susceptibility and clinical outcomes. Carcinogenesis. 2013;34(4):770-8.

\section{Tables}

Table 1. Characteristics of the subjects enrolled in the current study.

\begin{tabular}{cccccc}
\hline & Cervical cancer & CIN & Control & $F$ & $P$-value \\
\hline N & 1072 & 556 & 1262 & & \\
Age & $47.81 \pm 10.21$ & $47.42 \pm 9.37$ & $48.28 \pm 9.60$ & 1.438 & 0.238 \\
Pathological types & & & & \\
SCC & 903 & & & \\
AC & 151 & & & \\
Others & 18 & & & \\
Stages of CIN & & 65 & & \\
-ow degrade of CIN (I/II) & & 491 & & \\
figh Degrade of CIN (III) & & & & &
\end{tabular}

Note: SCC, squamous cell carcinoma; AC, Adenocarcinoma.

Table 2. The allelic and genotypic distribution among control, CIN and cervical cancer groups of SNPs in ERAP1 gene 


\begin{tabular}{|c|c|c|c|c|c|c|c|c|c|}
\hline \multirow[t]{2}{*}{ SNPs } & \multirow[t]{2}{*}{$\begin{array}{l}\text { Control } \\
\text { (Freq) }\end{array}$} & \multirow[t]{2}{*}{$\begin{array}{l}\text { CIN } \\
\text { (Freq) }\end{array}$} & \multirow{2}{*}{$\begin{array}{l}\text { Cervical } \\
\text { cancer } \\
\text { (Freq) }\end{array}$} & \multicolumn{2}{|c|}{$\begin{array}{c}\text { Cervical cancer vs } \\
\text { Control }\end{array}$} & \multicolumn{2}{|c|}{ CIN vs Control } & \multicolumn{2}{|c|}{$\begin{array}{c}\text { Cervical cancer } \\
\text { vs CIN }\end{array}$} \\
\hline & & & & $\begin{array}{c}P \text { - } \\
\text { value }\end{array}$ & OR[95\%CI] & $P$-value & OR[95\%CI] & $\begin{array}{c}\overline{P-} \\
\text { value }\end{array}$ & OR[95\%CI] \\
\hline \multicolumn{10}{|c|}{ rs27037 } \\
\hline G & $1372(54.4 \%)$ & $592(53.2 \%)$ & $1092(50.9 \%)$ & 0.020 & $0.872[0.777-$ & 0.532 & $0.956[0.830-$ & 0.212 & $0.912[0.789-$ \\
\hline $\mathrm{T}$ & $1152(45.6 \%)$ & $520(46.8 \%)$ & $1052(49.1 \%)$ & & $0.978]$ & & $1.101]$ & & $1.054]$ \\
\hline $\mathrm{G} / \mathrm{G}$ & $359(28.4 \%)$ & $161(29.0 \%)$ & $283(26.4 \%)$ & 0.020 & & 0.323 & & 0.462 & \\
\hline $\mathrm{G} / \mathrm{T}$ & $654(51.8 \%)$ & $270(48.6 \%)$ & $526(49.1 \%)$ & & & & & & \\
\hline $\mathrm{T} / \mathrm{T}$ & $249(19.8 \%)$ & $125(22.5 \%)$ & $263(24.5 \%)$ & & & & & & \\
\hline \multicolumn{10}{|c|}{ rs27044 } \\
\hline G & $1350(53.5 \%)$ & $611(54.9 \%)$ & $1240(57.8 \%)$ & 0.003 & $1.193[1.062-$ & 0.416 & $1.061[0.920-$ & 0.114 & $1.125[0.972-$ \\
\hline $\mathrm{C}$ & $1174(46.5 \%)$ & $501(45.1 \%)$ & $904(42.2 \%)$ & & $1.340]$ & & $1.222]$ & & $1.301]$ \\
\hline $\mathrm{G} / \mathrm{G}$ & $362(28.7 \%)$ & $175(31.5 \%)$ & $360(33.6 \%)$ & 0.012 & & 0.454 & & 0.196 & \\
\hline $\mathrm{G} / \mathrm{C}$ & $626(49.6 \%)$ & $261(46.9 \%)$ & $520(48.5 \%)$ & & & & & & \\
\hline $\mathrm{C} / \mathrm{C}$ & $274(21.7 \%)$ & $120(21.6 \%)$ & $192(17.9 \%)$ & & & & & & \\
\hline \multicolumn{10}{|c|}{ rs30187 } \\
\hline $\mathrm{C}$ & $1318(52.2 \%)$ & $589(53.0 \%)$ & $1203(56.1 \%)$ & 0.008 & $1.170[1.042-$ & 0.678 & $1.030[0.895-$ & 0.087 & $1.135[0.982-$ \\
\hline $\mathrm{T}$ & $1206(47.8 \%)$ & $523(47.0 \%)$ & $941(43.9 \%)$ & & $1.313]$ & & $1.187]$ & & 1.313] \\
\hline $\mathrm{C} / \mathrm{C}$ & $343(27.2 \%)$ & $169(30.4 \%)$ & $347(32.4 \%)$ & 0.020 & & 0.151 & & 0.134 & \\
\hline $\mathrm{C} / \mathrm{T}$ & $632(50.0 \%)$ & $251(45.1 \%)$ & $509(47.5 \%)$ & & & & & & \\
\hline $\mathrm{T} / \mathrm{T}$ & $287(22.8 \%)$ & $136(24.5 \%)$ & $216(20.1 \%)$ & & & & & & \\
\hline \multicolumn{10}{|c|}{ rs26618 } \\
\hline $\mathrm{T}$ & $1852(73.4 \%)$ & $785(70.6 \%)$ & $1508(70.3 \%)$ & 0.021 & $1.162[1.023-$ & 0.083 & $1.148[0.982-$ & 0.879 & $1.012[0.863-$ \\
\hline $\mathrm{C}$ & $672(26.6 \%)$ & $327(29.4 \%)$ & $636(29.7 \%)$ & & $1.321]$ & & $1.342]$ & & 1.187] \\
\hline $\mathrm{T} / \mathrm{T}$ & $678(53.7 \%)$ & $285(51.3 \%)$ & $546(50.9 \%)$ & 0.016 & & 0.076 & & 0.989 & \\
\hline $\mathrm{C} / \mathrm{T}$ & $496(39.3 \%)$ & $215(38.7 \%)$ & $416(38.8 \%)$ & & & & & & \\
\hline $\mathrm{C} / \mathrm{C}$ & $88(7.0 \%)$ & $56(10.1 \%)$ & $110(10.3 \%)$ & & & & & & \\
\hline \multicolumn{10}{|c|}{ rs26653 } \\
\hline $\mathrm{C}$ & $1227(48.6 \%)$ & $574(51.6 \%)$ & $1143(53.3 \%)$ & 0.001 & $0.829[0.738-$ & 0.095 & $0.887[0.770-$ & 0.359 & $0.934[0.808-$ \\
\hline G & $1297(51.4 \%)$ & $538(48.4 \%)$ & $1001(46.7 \%)$ & & 0.930] & & $1.021]$ & & $1.080]$ \\
\hline $\mathrm{C} / \mathrm{C}$ & $281(22.3 \%)$ & $142(25.5 \%)$ & $299(27.9 \%)$ & 0.004 & & 0.224 & & 0.591 & \\
\hline $\mathrm{G} / \mathrm{C}$ & $665(52.7 \%)$ & $290(52.2 \%)$ & $545(50.8 \%)$ & & & & & & \\
\hline $\mathrm{G} / \mathrm{G}$ & $316(25.0 \%)$ & $124(22.3 \%)$ & $228(21.3 \%)$ & & & & & & \\
\hline \multicolumn{10}{|c|}{ rs3734016 } \\
\hline $\mathrm{C}$ & $2159(85.5 \%)$ & $947(85.2 \%)$ & $1801(84.0 \%)$ & 0.145 & $\begin{array}{c}0.888[0.756- \\
1.041]\end{array}$ & 0.767 & $\begin{array}{c}0.970[0.795- \\
1.184]\end{array}$ & 0.387 & $\begin{array}{c}0.915[0.748- \\
1.119]\end{array}$ \\
\hline $\mathrm{T}$ & $365(14.5 \%)$ & $165(14.8 \%)$ & $343(16.0 \%)$ & & & & & & \\
\hline $\mathrm{C} / \mathrm{C}$ & $921(73.0 \%)$ & $404(72.7 \%)$ & $752(70.1 \%)$ & 0.318 & & 0.832 & & 0.500 & \\
\hline $\mathrm{C} / \mathrm{T}$ & $317(25.1 \%)$ & $139(25.0 \%)$ & $297(27.7 \%)$ & & & & & & \\
\hline $\mathrm{T} / \mathrm{T}$ & $24(1.9 \%)$ & 13(2.3\%) & $23(2.1 \%)$ & & & & & & \\
\hline
\end{tabular}

Note: The statistical significant threshold was set at $P<0.0045$ after Bonferroni correction.

Table 3. The allelic and genotypic distribution among control, CIN and cervical cancer groups of SNPs in ERAP2 gene 


\begin{tabular}{|c|c|c|c|c|c|c|c|c|c|}
\hline \multirow[t]{2}{*}{ SNPs } & \multirow[t]{2}{*}{ Control (Freq) } & \multirow{2}{*}{$\begin{array}{l}\text { CIN } \\
\text { (Freq) }\end{array}$} & \multirow{2}{*}{$\begin{array}{c}\text { Cervical } \\
\text { cancer (Freq) }\end{array}$} & \multicolumn{2}{|c|}{$\begin{array}{c}\text { Cervical } \\
\text { cancer vs Control }\end{array}$} & \multicolumn{2}{|c|}{ CIN vs Control } & \multicolumn{2}{|c|}{ Cervical cancer vs CIN } \\
\hline & & & & $\begin{array}{c}P \text { - } \\
\text { value }\end{array}$ & OR[95\%CI] & $P$-value & OR[95\%CI $]$ & $\begin{array}{c}P \text { - } \\
\text { value }\end{array}$ & OR[95\%CI $]$ \\
\hline \multicolumn{10}{|c|}{ rs2549782 } \\
\hline $\mathrm{T}$ & $1418(56.2 \%)$ & $628(56.5 \%)$ & $1146(53.5 \%)$ & 0.062 & $1.117[0.995-$ & 0.869 & $0.988[0.857-$ & 0.100 & $1.130[0.977-$ \\
\hline $\mathrm{G}$ & $1106(43.8 \%)$ & $484(43.5 \%)$ & $998(46.5 \%)$ & & $1.253]$ & & 1.139] & & $1.307]$ \\
\hline $\mathrm{T} / \mathrm{T}$ & $395(31.3 \%)$ & $173(31.1 \%)$ & $291(27.1 \%)$ & 0.089 & & 0.906 & & 0.214 & \\
\hline $\mathrm{G} / \mathrm{T}$ & $628(49.8 \%)$ & $282(50.7 \%)$ & $564(52.6 \%)$ & & & & & & \\
\hline $\mathrm{G} / \mathrm{G}$ & $239(18.9 \%)$ & $101(18.2 \%)$ & $217(20.2 \%)$ & & & & & & \\
\hline \multicolumn{10}{|c|}{ rs2548538 } \\
\hline A & 1063(42.1\%) & $474(42.6 \%)$ & $959(44.7 \%)$ & 0.073 & $1.112[0.990-$ & 0.774 & $1.021[0.885-$ & 0.252 & $1.089[0.941-$ \\
\hline $\mathrm{T}$ & $1461(57.9 \%)$ & $638(57.4 \%)$ & $1185(55.3 \%)$ & & $1.249]$ & & $1.178]$ & & $1.261]$ \\
\hline $\mathrm{A} / \mathrm{A}$ & $240(19.0 \%)$ & $107(19.2 \%)$ & $224(20.9 \%)$ & 0.197 & & 0.948 & & 0.524 & \\
\hline $\mathrm{A} / \mathrm{T}$ & $583(46.2 \%)$ & $260(46.8 \%)$ & $511(47.7 \%)$ & & & & & & \\
\hline $\mathrm{T} / \mathrm{T}$ & $439(34.8 \%)$ & $189(34.0 \%)$ & $337(31.4 \%)$ & & & & & & \\
\hline \multicolumn{10}{|c|}{ rs2248374 } \\
\hline A & $1128(44.7 \%)$ & $487(43.8 \%)$ & 1035(48.3\%) & 0.014 & $1.155[1.029-$ & 0.616 & $0.964[0.837-$ & 0.015 & $1.198[1.035-$ \\
\hline G & $1396(55.3 \%)$ & $625(56.2 \%)$ & $1109(51.7 \%)$ & & $1.296]$ & & 1.116] & & $1.386]$ \\
\hline $\mathrm{A} / \mathrm{A}$ & 248(19.7\%) & $100(18.0 \%)$ & $232(21.6 \%)$ & 0.020 & & 0.690 & & 0.041 & \\
\hline $\mathrm{A} / \mathrm{G}$ & $632(50.0 \%)$ & $287(51.6 \%)$ & $571(53.3 \%)$ & & & & & & \\
\hline $\mathrm{G} / \mathrm{G}$ & $382(30.3 \%)$ & $169(30.4 \%)$ & $269(25.1 \%)$ & & & & & & \\
\hline \multicolumn{10}{|c|}{ rs2287988 } \\
\hline A & $1407(55.7 \%)$ & $623(56.0 \%)$ & $1104(51.5 \%)$ & 0.004 & $0.843[0.751-$ & 0.875 & $1.011[0.877-$ & 0.014 & $0.833[0.720-$ \\
\hline $\mathrm{G}$ & $1117(44.3 \%)$ & $489(44.0 \%)$ & $1040(48.5 \%)$ & & $0.946]$ & & 1.166] & & 0.964] \\
\hline $\mathrm{A} / \mathrm{A}$ & $387(30.7 \%)$ & $167(30.0 \%)$ & $267(24.9 \%)$ & 0.007 & & 0.743 & & 0.039 & \\
\hline $\mathrm{A} / \mathrm{G}$ & $633(50.1 \%)$ & $289(52.0 \%)$ & $570(53.2 \%)$ & & & & & & \\
\hline $\mathrm{G} / \mathrm{G}$ & $242(19.2 \%)$ & $100(18.0 \%)$ & $235(21.9 \%)$ & & & & & & \\
\hline \multicolumn{10}{|c|}{ rs1056983 } \\
\hline C & $1062(42.1 \%)$ & $465(41.8 \%)$ & $919(42.9 \%)$ & 0.587 & $\begin{array}{c}1.033[0.919- \\
1.160]\end{array}$ & 0.884 & $\begin{array}{c}0.989[0.858- \\
1.141]\end{array}$ & 0.567 & $\begin{array}{c}1.044[0.901- \\
1.209]\end{array}$ \\
\hline $\mathrm{T}$ & $1462(57.9 \%)$ & $647(58.2 \%)$ & $1225(57.1 \%)$ & & & & & & \\
\hline $\mathrm{C} / \mathrm{C}$ & $239(18.9 \%)$ & $104(18.7 \%)$ & $207(19.3 \%)$ & 0.830 & & 0.990 & & 0.831 & \\
\hline $\mathrm{C} / \mathrm{T}$ & $584(46.3 \%)$ & $257(46.2 \%)$ & $505(47.1 \%)$ & & & & & & \\
\hline $\mathrm{T} / \mathrm{T}$ & $439(34.8 \%)$ & $195(35.1 \%)$ & $360(33.6 \%)$ & & & & & & \\
\hline
\end{tabular}

Note: The statistical significant threshold was set at $P<0.0045$ after Bonferroni correction.

Table 4. Inheritance model analysis of SNPs in ERAP1 gene between control and cervical cancer groups 


\begin{tabular}{|c|c|c|c|c|c|c|c|c|}
\hline SNPs & Models & Genotypes & Control (Freq) & Cervical cancer (Freq) & OR[95\%CI] & $P$-value & AIC & BIC \\
\hline \multirow[t]{8}{*}{ rs27037 } & Condominant & $\mathrm{G} / \mathrm{G}$ & $359(28.4 \%)$ & $283(26.4 \%)$ & 1 & 0.020 & 3218.2 & 3241.2 \\
\hline & & $\mathrm{G} / \mathrm{T}$ & $654(51.8 \%)$ & $526(49.1 \%)$ & $1.02(0.84-1.23)$ & & & \\
\hline & & $\mathrm{T} / \mathrm{T}$ & 249 (19.8\%) & $263(24.5 \%)$ & $1.34(1.06-1.69)$ & & & \\
\hline & Dominant & $\mathrm{G} / \mathrm{G}$ & $359(28.4 \%)$ & $283(26.4 \%)$ & 1 & 0.280 & 3222.8 & 3240.1 \\
\hline & & $\mathrm{G} / \mathrm{T}-\mathrm{T} / \mathrm{T}$ & $903(71.6 \%)$ & 789 (73.6\%) & $1.11(0.92-1.33)$ & & & \\
\hline & Recessive & G/G-G/T & $1013(80.2 \%)$ & 809 (75.5\%) & 1 & 0.006 & 3216.2 & 3233.5 \\
\hline & & $\mathrm{T} / \mathrm{T}$ & $249(19.8 \%)$ & $263(24.5 \%)$ & $1.32(1.09-1.61)$ & & & \\
\hline & Log-additive & --- & --- & --- & $1.15(1.02-1.29)$ & 0.020 & 3218.6 & 3235.8 \\
\hline \multirow[t]{8}{*}{ rs27044 } & Condominant & G/G & $362(28.7 \%)$ & $360(33.6 \%)$ & 1 & 0.012 & 3217.2 & 3240.2 \\
\hline & & $\mathrm{G} / \mathrm{C}$ & $626(49.6 \%)$ & 520 (48.5\%) & $0.84(0.70-1.01)$ & & & \\
\hline & & $\mathrm{C} / \mathrm{C}$ & 274 (21.7\%) & 192 (17.9\%) & $0.71(0.56-0.89)$ & & & \\
\hline & Dominant & $\mathrm{G} / \mathrm{G}$ & 362 (28.7\%) & 360 (33.6\%) & 1 & 0.012 & 3217.6 & 3234.9 \\
\hline & & $\mathrm{G} / \mathrm{C}-\mathrm{C} / \mathrm{C}$ & 900 (71.3\%) & $712(66.4 \%)$ & $0.80(0.67-0.95)$ & & & \\
\hline & Recessive & $\mathrm{G} / \mathrm{G}-\mathrm{G} / \mathrm{C}$ & 988 (78.3\%) & 880 (82.1\%) & 1 & 0.021 & 3218.7 & 3235.9 \\
\hline & & $\mathrm{C} / \mathrm{C}$ & $274(21.7 \%)$ & 192 (17.9\%) & $0.79(0.64-0.97)$ & & & \\
\hline & Log-additive & --- & --- & --- & $0.84(0.75-0.94)$ & 0.003 & 3215.2 & 3232.5 \\
\hline \multirow[t]{8}{*}{ rs30187 } & Condominant & $\mathrm{C} / \mathrm{C}$ & $343(27.2 \%)$ & 347 (32.4\%) & 1 & 0.020 & 3218.2 & 3241.2 \\
\hline & & $\mathrm{C} / \mathrm{T}$ & $632(50.0 \%)$ & 509 (47.5\%) & $0.80(0.66-0.96)$ & & & \\
\hline & & $\mathrm{T} / \mathrm{T}$ & 287 (22.8\%) & 216 (20.1\%) & $0.74(0.59-0.94)$ & & & \\
\hline & Dominant & $\mathrm{C} / \mathrm{C}$ & $343(27.2 \%)$ & 347 (32.4\%) & 1 & 0.007 & 3216.6 & 3233.9 \\
\hline & & $\mathrm{C} / \mathrm{T}-\mathrm{T} / \mathrm{T}$ & 919 (72.8\%) & 725 (67.6\%) & $0.78(0.65-0.93)$ & & & \\
\hline & Recessive & $\mathrm{C} / \mathrm{C}-\mathrm{C} / \mathrm{T}$ & 975 (77.2\%) & 856 (79.8\%) & 1 & 0.120 & 3221.6 & 3238.9 \\
\hline & & $\mathrm{T} / \mathrm{T}$ & 287 (22.8\%) & 216 (20.1\%) & $0.86(0.70-1.04)$ & & & \\
\hline & Log-additive & --- & --- & --- & $0.86(0.76-0.96)$ & 0.009 & 3217.1 & 3234.3 \\
\hline \multirow[t]{8}{*}{ rs26618 } & Condominant & $\mathrm{T} / \mathrm{T}$ & 678 (53.7\%) & 546 (50.9\%) & 1 & 0.016 & 3217.7 & 3240.7 \\
\hline & & $\mathrm{C} / \mathrm{T}$ & 496 (39.3\%) & 416 (38.8\%) & $1.04[0.88-1.24]$ & & & \\
\hline & & $\mathrm{C} / \mathrm{C}$ & 88 (7.0\%) & $110(10.3 \%)$ & $1.55[1.15-2.10]$ & & & \\
\hline & Dominant & $\mathrm{T} / \mathrm{T}$ & $678(53.7 \%)$ & 546 (50.9\%) & 1 & 0.180 & 3222.2 & 3239.5 \\
\hline & & $\mathrm{C} / \mathrm{T}-\mathrm{C} / \mathrm{C}$ & 584 (46.3\%) & $526(49.1 \%)$ & $1.12[0.95-1.32]$ & & & \\
\hline & Recessive & $\mathrm{T} / \mathrm{T}-\mathrm{C} / \mathrm{T}$ & $1174(93.0 \%)$ & 962 (89.7\%) & 1 & 0.004 & 3215.9 & 3233.1 \\
\hline & & $\mathrm{C} / \mathrm{C}$ & 88 (7.0\%) & $110(10.3 \%)$ & $1.53[1.14-2.05]$ & & & \\
\hline & Log-additive & --- & --- & --- & $1.16[1.02-1.31]$ & 0.023 & 3218.9 & 3236.1 \\
\hline \multirow[t]{8}{*}{ rs26653 } & Condominant & $\mathrm{C} / \mathrm{C}$ & $281(22.3 \%)$ & 299 (27.9\%) & 1 & 0.004 & 3214.8 & 3237.8 \\
\hline & & $\mathrm{C} / \mathrm{G}$ & $665(52.7 \%)$ & 545 (50.8\%) & $0.77[0.63-0.94]$ & & & \\
\hline & & $\mathrm{G} / \mathrm{G}$ & $316(25.0 \%)$ & 228 (21.3\%) & $0.68[0.54-0.86]$ & & & \\
\hline & Dominant & $\mathrm{C} / \mathrm{C}$ & 281 (22.3\%) & 299 (27.9\%) & 1 & 0.002 & 3214.2 & 3231.5 \\
\hline & & $\mathrm{C} / \mathrm{G}-\mathrm{G} / \mathrm{G}$ & 981 (77.7\%) & 773 (72.1\%) & 0.74 [0.61-0.89] & & & \\
\hline & Recessive & $\mathrm{C} / \mathrm{C}-\mathrm{C} / \mathrm{G}$ & 946 (75.0\%) & 844 (78.7\%) & 1 & 0.034 & 3219.5 & 3236.7 \\
\hline & & G/G & $316(25.0 \%)$ & $228(21.3 \%)$ & $0.81[0.67-0.98]$ & & & \\
\hline & Log-additive & --- & --- & --- & $0.82[0.73-0.93]$ & 0.001 & 3213.5 & 3230.7 \\
\hline \multirow[t]{4}{*}{ rs3734016 } & Condominant & $\mathrm{C} / \mathrm{C}$ & 921 (73.0\%) & 752 (70.2\%) & 1 & 0.330 & 3223.8 & 3246.8 \\
\hline & & $\mathrm{C} / \mathrm{T}$ & 317 (25.1\%) & 297 (27.7\%) & $1.15(0.95-1.38)$ & & & \\
\hline & & $\mathrm{T} / \mathrm{T}$ & 24 (1.9\%) & 23 (2.1\%) & $1.17(0.65-2.09)$ & & & \\
\hline & Dominant & $\mathrm{C} / \mathrm{C}$ & 921 (73.0\%) & $752(70.2 \%)$ & 1 & 0.140 & 3221.8 & 3239.0 \\
\hline
\end{tabular}




\begin{tabular}{cccccccc} 
& $\mathrm{C} / \mathrm{T}-\mathrm{T} / \mathrm{T}$ & $341(27.0 \%)$ & $320(29.9 \%)$ & $1.15(0.96-1.37)$ & & \\
Recessive & $\mathrm{C} / \mathrm{C}-\mathrm{C} / \mathrm{T}$ & $1238(98.1 \%)$ & $1049(97.8 \%)$ & 1 & 0.690 & 3223.8 & 3241.1 \\
& $\mathrm{~T} / \mathrm{T}$ & $24(1.9 \%)$ & $23(2.1 \%)$ & $1.13(0.63-2.01)$ & & \\
Log-additive & --- & --- & --- & $1.13(0.96-1.33)$ & 0.150 & 3221.9 & 3239.1 \\
\hline
\end{tabular}

Note: The statistical significant threshold was set at $P<0.0045$ after Bonferroni correction.

Table 5. Inheritance model analysis of SNPs in ERAP2 gene between control and cervical cancer groups

\begin{tabular}{|c|c|c|c|c|c|c|c|c|}
\hline SNPs & Models & Genotypes & Control (Freq) & Cervical cancer (Freq) & OR[95\%CI] & $P$-value & AIC & BIC \\
\hline \multirow[t]{8}{*}{ rs2549782 } & Codominant & $\mathrm{T} / \mathrm{T}$ & $395(31.3 \%)$ & $291(27.1 \%)$ & 1 & 0.088 & 3221.1 & 3244.2 \\
\hline & & $\mathrm{G} / \mathrm{T}$ & $628(49.8 \%)$ & $564(52.6 \%)$ & $1.22(1.01-1.47)$ & & & \\
\hline & & G/G & $239(18.9 \%)$ & $217(20.2 \%)$ & $1.23(0.97-1.56)$ & & & \\
\hline & Dominant & $\mathrm{T} / \mathrm{T}$ & 395 (31.3\%) & $291(27.1 \%)$ & 1 & 0.028 & 3219.2 & 3236.4 \\
\hline & & $\mathrm{G} / \mathrm{T}-\mathrm{G} / \mathrm{G}$ & $867(68.7 \%)$ & 781 (72.8\%) & $1.22(1.02-1.46)$ & & & \\
\hline & Recessive & $\mathrm{T} / \mathrm{T}-\mathrm{G} / \mathrm{T}$ & $1023(81.0 \%)$ & $855(79.8 \%)$ & 1 & 0.430 & 3223.4 & 3240.6 \\
\hline & & $\mathrm{G} / \mathrm{G}$ & $239(18.9 \%)$ & $217(20.2 \%)$ & $1.09(0.89-1.33)$ & & & \\
\hline & Log-additive & --- & --- & --- & $1.12(1.00-1.26)$ & 0.057 & 3220.4 & 3237.6 \\
\hline \multirow[t]{8}{*}{ rs2548538 } & Condominant & $\mathrm{T} / \mathrm{T}$ & $439(34.8 \%)$ & 337 (31.4\%) & 1 & 0.200 & 3222.8 & 3245.8 \\
\hline & & $\mathrm{A} / \mathrm{T}$ & $583(46.2 \%)$ & 511 (47.7\%) & $1.14(0.95-1.37)$ & & & \\
\hline & & $\mathrm{A} / \mathrm{A}$ & 240 (19.0\%) & 224 (20.9\%) & $1.22(0.96-1.53)$ & & & \\
\hline & Dominant & $\mathrm{T} / \mathrm{T}$ & 439 (34.8\%) & 337 (31.4\%) & 1 & 0.089 & 3221.1 & 3238.4 \\
\hline & & $\mathrm{A} / \mathrm{T}-\mathrm{A} / \mathrm{A}$ & $823(65.2 \%)$ & 735 (68.6\%) & $1.16(0.98-1.38)$ & & & \\
\hline & Recessive & $\mathrm{T} / \mathrm{T}-\mathrm{A} / \mathrm{T}$ & 1022 (81.0\%) & 848 (79.1\%) & 1 & 0.260 & 3222.7 & 3240.0 \\
\hline & & $\mathrm{A} / \mathrm{A}$ & $240(19.0 \%)$ & 224 (20.9\%) & $1.12(0.92-1.38)$ & & & \\
\hline & Log-additive & --- & --- & --- & $1.11(0.99-1.24)$ & 0.080 & 3220.9 & 3238.2 \\
\hline \multirow{8}{*}{ rs2248374 } & Condominant & $\mathrm{G} / \mathrm{G}$ & $382(30.3 \%)$ & $269(25.1 \%)$ & 1 & 0.020 & 3218.1 & 3241.2 \\
\hline & & $\mathrm{A} / \mathrm{G}$ & $632(50.0 \%)$ & 571 (53.3\%) & $1.28(1.06-1.56)$ & & & \\
\hline & & $\mathrm{A} / \mathrm{A}$ & $248(19.7 \%)$ & 232 (21.6\%) & $1.33(1.05-1.69)$ & & & \\
\hline & Dominant & $\mathrm{G} / \mathrm{G}$ & $382(30.3 \%)$ & 269 (25.1\%) & 1 & 0.005 & 3216.2 & 3233.5 \\
\hline & & A/G-A/A & $880(69.7 \%)$ & 803 (74.9\%) & $1.30(1.08-1.56)$ & & & \\
\hline & Recessive & G/G-A/G & $1014(80.3 \%)$ & 840 (78.4\%) & 1 & 0.230 & 3222.6 & 3239.8 \\
\hline & & $\mathrm{A} / \mathrm{A}$ & 248 (19.7\%) & $232(21.6 \%)$ & $1.13(0.92-1.38)$ & & & \\
\hline & Log-additive & --- & --- & --- & $1.16(1.03-1.31)$ & 0.012 & 3217.7 & 3235.0 \\
\hline \multirow[t]{8}{*}{ rs2287988 } & Codominant & $\mathrm{A} / \mathrm{A}$ & 387 (30.7\%) & 267 (24.9\%) & 1 & 0.007 & 3216.0 & 3239.0 \\
\hline & & $A / G$ & $633(50.1 \%)$ & $570(53.2 \%)$ & $1.30(1.07-1.58)$ & & & \\
\hline & & $\mathrm{G} / \mathrm{G}$ & $242(19.2 \%)$ & 235 (21.9\%) & $1.41(1.11-1.78)$ & & & \\
\hline & Dominant & $\mathrm{A} / \mathrm{A}$ & $387(30.7 \%)$ & 267 (24.9\%) & 1 & 0.002 & 3214.5 & 3231.8 \\
\hline & & A/G-G/G & 875 (69.3\%) & 805 (75.1\%) & $1.33(1.11-1.60)$ & & & \\
\hline & Recessive & $\mathrm{A} / \mathrm{A}-\mathrm{A} / \mathrm{G}$ & 1020 (80.8\%) & 837 (78.1\%) & 1 & 0.100 & 3221.3 & 3238.6 \\
\hline & & $\mathrm{G} / \mathrm{G}$ & 242 (19.2\%) & 235 (21.9\%) & $1.18(0.97-1.45)$ & & & \\
\hline & Log-additive & --- & --- & --- & $1.19(1.06-1.34)$ & 0.003 & 3215.3 & 3232.5 \\
\hline \multirow[t]{8}{*}{ rs1056983 } & Condominant & $\mathrm{T} / \mathrm{T}$ & 439 (34.8\%) & 360 (33.6\%) & 1 & 0.820 & 3225.6 & 3248.6 \\
\hline & & $\mathrm{C} / \mathrm{T}$ & $584(46.3 \%)$ & 505 (47.1\%) & $1.06(0.88-1.27)$ & & & \\
\hline & & $\mathrm{C} / \mathrm{C}$ & 239 (18.9\%) & 207 (19.3\%) & $1.06(0.84-1.34)$ & & & \\
\hline & Dominant & $\mathrm{T} / \mathrm{T}$ & 439 (34.8\%) & 360 (33.6\%) & 1 & 0.530 & 3223.6 & 3240.9 \\
\hline & & $\mathrm{C} / \mathrm{T}-\mathrm{C} / \mathrm{C}$ & 823 (65.2\%) & 712 (66.4\%) & $1.06(0.89-1.25)$ & & & \\
\hline & Recessive & $\mathrm{T} / \mathrm{T}-\mathrm{C} / \mathrm{T}$ & 1023 (81.0\%) & 865 (80.7\%) & 1 & 0.810 & 3223.9 & 3241.2 \\
\hline & & $\mathrm{C} / \mathrm{C}$ & 239 (18.9\%) & 207 (19.3\%) & $1.03(0.83-1.26)$ & & & \\
\hline & Log-additive & --- & --- & --- & $1.03(0.92-1.16)$ & 0.580 & 3223.7 & 3241.0 \\
\hline
\end{tabular}

Note: The statistical significant threshold was set at $P<0.0045$ after Bonferroni correction.

Table 6. The distribution of the haplotypes constructed by SNPs in ERAP1 gene 


\begin{tabular}{|c|c|c|c|c|c|c|c|c|c|}
\hline \multirow[t]{2}{*}{ Haplotypes } & \multirow[t]{2}{*}{$\begin{array}{l}\text { Control } \\
\text { (Freq) }\end{array}$} & \multirow[t]{2}{*}{$\begin{array}{c}\text { CIN } \\
\text { (Freq) }\end{array}$} & \multirow{2}{*}{$\begin{array}{c}\text { Cervical } \\
\text { cancer } \\
\text { (Freq) }\end{array}$} & \multicolumn{2}{|c|}{$\begin{array}{c}\text { Cervical cancer vs } \\
\text { Control }\end{array}$} & \multicolumn{2}{|c|}{$\begin{array}{l}\text { CIN vs } \\
\text { Control }\end{array}$} & \multicolumn{2}{|c|}{ Cervical cancer vs CIN } \\
\hline & & & & $P$-value & OR[95\%CI] & $\begin{array}{c}\overline{P-} \\
\text { value }\end{array}$ & OR[95\%CI] & $\begin{array}{c}P \text { - } \\
\text { value }\end{array}$ & OR[95\%CI] \\
\hline G-C-C-C-C & $\begin{array}{l}646.12 \\
(0.256)\end{array}$ & $\begin{array}{l}299.22 \\
(0.269)\end{array}$ & $\begin{array}{l}556.04 \\
(0.259)\end{array}$ & 0.041 & $\begin{array}{c}1.151 \\
{[1.006-1.316]}\end{array}$ & 0.122 & $\begin{array}{c}1.137 \\
{[0.966-1.338]}\end{array}$ & 0.890 & $\begin{array}{c}1.012 \\
{[0.855-1.197]}\end{array}$ \\
\hline G-T-T-G-C & $\begin{array}{c}76.43 \\
(0.030)\end{array}$ & $\begin{array}{c}37.05 \\
(0.033)\end{array}$ & $\begin{array}{c}64.76 \\
(0.030)\end{array}$ & 0.612 & $\begin{array}{c}1.091 \\
{[0.779-1.528]}\end{array}$ & 0.486 & $\begin{array}{c}1.153 \\
{[0.773-1.719]}\end{array}$ & 0.794 & $\begin{array}{c}0.947 \\
{[0.627-1.428]}\end{array}$ \\
\hline C-T-T-G-C & $\begin{array}{l}1101.70 \\
(0.437)\end{array}$ & $\begin{array}{l}444.48 \\
(0.400)\end{array}$ & $\begin{array}{l}759.76 \\
(0.354)\end{array}$ & 0.001 & $\begin{array}{c}0.804 \\
{[0.711-0.910]}\end{array}$ & 0.260 & $\begin{array}{c}0.918 \\
{[0.791-1.065]}\end{array}$ & 0.096 & $\begin{array}{c}0.876[0.750- \\
1.024]\end{array}$ \\
\hline G-C-T-C-C & $\begin{array}{l}196.08 \\
(0.078)\end{array}$ & $\begin{array}{c}72.59 \\
(0.065)\end{array}$ & $\begin{array}{l}176.09 \\
(0.082)\end{array}$ & 0.150 & $\begin{array}{c}1.169 \\
{[0.945-1.447]}\end{array}$ & 0.315 & $\begin{array}{c}0.866 \\
{[0.655-1.146]}\end{array}$ & 0.039 & $\begin{array}{c}1.350 \\
{[1.015-1.795]}\end{array}$ \\
\hline G-C-T-C-T & $\begin{array}{l}336.22 \\
(0.133)\end{array}$ & $\begin{array}{l}142.58 \\
(0.128)\end{array}$ & $\begin{array}{l}278.80 \\
(0.130)\end{array}$ & 0.402 & $\begin{array}{c}1.076 \\
{[0.906-1.278]}\end{array}$ & 0.970 & $\begin{array}{c}1.004 \\
{[0.813-1.241]}\end{array}$ & 0.533 & $\begin{array}{c}1.072[0.862- \\
1.334]\end{array}$ \\
\hline
\end{tabular}

Note: The statistical significant threshold was set at $P<0.01(0.05 / \mathrm{n}, \mathrm{n}=5)$ after Bonferroni correction.

Table 7. The distribution of the haplotypes constructed by SNPs in ERAP2 gene

\begin{tabular}{|c|c|c|c|c|c|c|c|c|c|}
\hline \multirow[t]{2}{*}{ Haplotypes } & \multirow[t]{2}{*}{$\begin{array}{l}\text { Control } \\
\text { (Freq) }\end{array}$} & \multirow[t]{2}{*}{$\begin{array}{l}\text { CIN } \\
\text { (Freq) }\end{array}$} & \multirow[t]{2}{*}{$\begin{array}{c}\text { Cervical } \\
\text { cancer(Freq) }\end{array}$} & \multicolumn{2}{|c|}{$\begin{array}{c}\text { Cervical cancer vs } \\
\text { Control }\end{array}$} & \multicolumn{2}{|c|}{ CIN vs Control } & \multicolumn{2}{|c|}{$\begin{array}{l}\text { Cervical cancer vs } \\
\text { CIN }\end{array}$} \\
\hline & & & & $\begin{array}{c}P- \\
\text { value }\end{array}$ & OR[95\%CI $]$ & $\begin{array}{c}P- \\
\text { value }\end{array}$ & OR[95\%CI $]$ & $\begin{array}{c}P- \\
\text { value }\end{array}$ & OR[95\%CI] \\
\hline G-A-A-G-C & $\begin{array}{l}953.78 \\
(0.378)\end{array}$ & $\begin{array}{l}411.75 \\
(0.370)\end{array}$ & $\begin{array}{l}784.87 \\
(0.366)\end{array}$ & 0.219 & $\begin{array}{c}1.080 \\
{[0.955-} \\
1.220]\end{array}$ & 0.908 & $\begin{array}{c}0.991 \\
{[0.852-} \\
1.153]\end{array}$ & 0.336 & $\begin{array}{c}1.079[0.925- \\
1.258]\end{array}$ \\
\hline G-A-A-G-T & $\begin{array}{c}58.71 \\
(0.023)\end{array}$ & $\begin{array}{l}20.26 \\
(0.018)\end{array}$ & $\begin{array}{c}72.44 \\
(0.034)\end{array}$ & 0.009 & $\begin{array}{c}1.592 \\
{[1.122-} \\
2.258]\end{array}$ & 0.053 & $\begin{array}{c}1.837 \\
{[0.983-} \\
3.434]\end{array}$ & 0.006 & $\begin{array}{c}2.000[1.215- \\
3.292]\end{array}$ \\
\hline G-T-A-G-C & $\begin{array}{c}61.18 \\
(0.024)\end{array}$ & $\begin{array}{c}25.61 \\
(0.023)\end{array}$ & $\begin{array}{c}71.82 \\
(0.033)\end{array}$ & 0.018 & $\begin{array}{c}1.513 \\
{[1.070-} \\
2.139]\end{array}$ & 0.638 & $\begin{array}{c}1.130 \\
{[0.678-} \\
1.884]\end{array}$ & 0.055 & $\begin{array}{c}1.560[0.987- \\
2.465]\end{array}$ \\
\hline T-T-G-A-T & $\begin{array}{c}1346.11 \\
(0.533)\end{array}$ & $\begin{array}{l}586.29 \\
(0.527)\end{array}$ & $\begin{array}{l}973.03 \\
(0.454)\end{array}$ & 0.003 & $\begin{array}{c}0.835 \\
{[0.740-} \\
0.942]\end{array}$ & 0.908 & $\begin{array}{c}1.009 \\
{[0.868-} \\
1.173]\end{array}$ & 0.009 & $\begin{array}{c}0.817[0.702- \\
0.951]\end{array}$ \\
\hline
\end{tabular}

Note: The statistical significant threshold was set at $P<0.012(0.05 / \mathrm{n}, \mathrm{n}=4)$ after Bonferroni correction.

\section{Supplementary Files}

This is a list of supplementary files associated with this preprint. Click to download.

- SupplementaryTables20200328.docx 